\title{
Distant Pedicled Flaps for Elbow Coverage- a Systematic Review
}

\section{Dirsek Bölgesi Defektlerinin Onarımında Uzak Pediküllü Flepler: Sistematik Derleme}

\author{
Ömer Berköz ${ }^{1} \oplus$, H. Utkan Aydın ${ }^{1} \oplus$
}

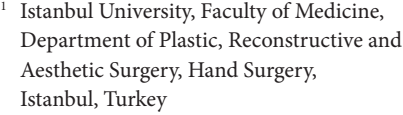

ORCID: Ö.B. 0000-0001-8063-9995; H.U.A. 0000-0001-7091-2599

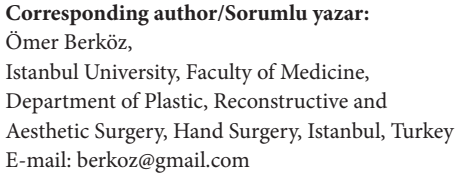

Submitted/Başvuru: 18.04 .2020

Accepted/Kabul: 24.05.2020

Citation/Atıf: Berkoz O, Aydin HU. Distant Pedicled Flaps for Elbow Coverage- a Systematic Review. Sağlık Bilimlerinde İleri Araştırmalar Dergisi 2020; 3(2): $72-80$

https://doi.org/10.26650/JARHS2020-722703

\begin{abstract}
Coverage of elbow defects can be challenging for reconstructive surgeons. The intended reconstruction not only has to cover and protect the underlying structures but also allow for smooth functioning of the joint. Even in the era of microsurgery, certain defects are not amenable to reconstruction with regional flaps or free flaps. Pedicled flaps from the abdomen play a critical role in such cases to salvage the elbow and hence the limb. While there are multiple such flaps mentioned, a systematic review is lacking. This systematic review aims to look at all the pedicled flaps from the abdomen to the elbow reported in the literature. After an extensive search of multiple databases, 159 articles were obtained, of which 31 were selected. The flaps reported in the selected articles were grouped into muscle/ musculocutaneous or skin/fasciocutaneous flaps. While the latissimus dorsi appeared to be the most utilized flap overall to cover the defect in the elbow region, paraumbilical perforator-based flaps were the most common among the fasciocutaneous flaps. This review highlights the commonly used flaps, and discusses the advantages and disadvantages of each. In view of the considerable overlapping names of various fasciocutaneous flaps, we offer a nomenclature for better communication and understanding.
\end{abstract}

Keywords: Elbow, reconstruction, pedicled flap

ÖZ

Dirsek bölgesi defektlerinin kapatılması rekonstrüktif cerrahlar için kendine özgü çeşitli güçlükler içerir. Amaçlanan rekonstrüksiyon sadece allta yatan yapıları örterek korumakla kalmamalı, aynı zamanda dirsek ekleminin sorunsuz hareketine de izin vermelidir. Mikrocerrahi cağında bile bazı defektlerin bölgesel ya da serbest fleplerle onarımı olanaklı olmayabilir. Bu tip olgularda abdomenden hazırlanan pediküllü flepler dirseğin ve dolayısı ile ve ekstremitenin kurtarılmasında çok önemli bir rol oynarlar. Bu amaçla pek cok flep tanımlanmış olsa da bu konu üzerine yazılmış derlemelerin sayısı kısıtlıdır. Bu sistematik derlemenin amacı literatürde dirsek bölgesi defektlerinin onarımı için abdomen bölgesinden hazırlanan flepleri konu alan çalışmaları gözden geçirmektir. Bu amaçla çesitli veri bankalarının kapsamlı taraması sonucu bulunan 159 makalenin 31 tanesi seçildi. Seçilen makalelerde bahsi geçen flepler kas / muskulokutan ya da cilt/ fasyokutan flepler olarak sınıflandırıldı. Genel olarak, latissimus dorsi flebi dirsek bölgesi fleplerinin kapatılması için kullanılan en yaygın flep olarak ortaya çıksa da, paraumblikal perforatörlere baze flepler en sık kullanılan fasyokütan flepler idi. Bu derleme, en sık kullanılan flepleri ortaya koyup bunların kullanımı ile ilgili avantaj ve dezavantajları tartışmaktadır. Farklı fasyokütan flepleri tanımlamak için kullanılan terimler arasında karışıklığa yol açacak derecede bir örtüşme olduğundan, bu fleplerin daha iyi anlaşılması ve daha iyi iletişim için yeni bir tanımlama şablonu da sunulmuștur.

Anahtar Kelimeler: Dirsek, rekonstrüksiyon, pediküllü flep 


\section{INTRODUCTION}

Elbow defects arise due to a variety of causes such as trauma, infection, burn contracture release or tumor excision. Defects around the elbow are challenging to manage due to a multitude of factors. The reconstruction should cover the exposed joint, bones, tendons, vessels, nerves, hardware and thus necessitate flap coverage. A pliable yet well-padded reconstruction is needed to prevent any contracture and to facilitate mobilization. The reconstruction should be durable and also allow for future procedures if needed. Finally, there should be minimal donor site morbidity.

For smaller defects of the elbow there are many options from the same arm. Transposition flaps, lateral arm flaps, radial artery flaps, posterior interosseous flaps and various local muscle flaps can be used (1-3). However, if the defect is large and the zone of injury extends further, local and regional flaps may not be sufficient. Healthy vascularized tissue needs to be brought in for reconstruction. This can be done in two ways, either as a free flap or as a pedicled flap from abdominal tissues. Free flaps have a unique set of advantages and disadvantages independent of the location of the defect. The recipient site considerations are related to finding suitable vessels for anastomosis. Nevertheless, free flaps are not always possible or successful. The donor vessels may be in the zone of trauma necessitating long vein grafts.

The alternative option is pedicled flaps from abdominal tissues. While there are different abdominal flaps mentioned, a detailed review is lacking. Most discussion on elbow coverage highlights various local flaps followed by free flaps with little description of pedicled flaps from the abdomen (4). However, many authors have noted that even in the era of microsurgery, the distant pedicled flaps have a role to play in elbow coverage (2-3). We believe that a review of literature to investigate all flaps for elbow coverage from abdomen with their anatomical basis, surgical technique and clinical outcome would be beneficial. The current study is based on reviewing the literature for various pedicled abdominal flaps for elbow coverage to highlight the indications, the advantages, and disadvantages.

\section{MATERIAL AND METHODS}

This systematic review was conducted following the guidelines published by Khan and colleagues (5). Review was done as per PRISMA guidelines. A search was carried out on various databases such as Scopus, Google Scholar, PubMed, Web of Science and Cochrane Library. The keywords "Elbow defect" and "Abdominal flap" were used to search the databases. The resulting articles were retrieved and the abstracts were read. Duplicated articles or articles not in English were excluded. Only articles pertaining to flap for elbow defect were selected. Full text articles were obtained and were read by two authors. Only relevant articles were selected.

The articles were included if they described any pedicled flap from abdomen to cover the defects around the elbow. The exclusion criteria were - the flap not from the abdomen, flap was a free flap, no clinical application mentioned or the defect was other than the elbow region. The references in the full text articles were reviewed for additional articles. The extracted articles were independently reviewed by two authors.

\section{RESULTS}

A total of 159 articles were obtained; 11 articles in Scopus, 5 articles in Web of Science, 109 articles in Google Scholar, 31 in PubMed and 3 in Cochrane Library. In the first step, the abstracts were read and duplicates were excluded- thus selecting 43 articles. In the second step, the full length articles were obtained and read. According to previously mentioned inclusion and exclusion criteria, a total of 29 articles were included. Two additional articles were obtained after searching the references. Hence a total of 31 articles were included.

Among the 31 articles, eight were case reports, 14 were case series with a single flap, 3 were case series with multiple flaps and six were review articles (Fig. 1). Various flaps were utilized for coverage of elbow defects. The types of flaps done from abdomen to the elbow region is shown in Table 1.

Latissimus dorsi flap, either as a muscle or myocutaneous, was by far the most common flap used for elbow coverage from the abdomen. This was followed by various fasciocutaneous flaps. There were rare instances of rectus muscle flap, parascapular flap, and bilateral groin flaps being used. 
Table 1. A summary of flaps from abdominal tissue to the elbow reported in the articles which are included in our systematic review

\begin{tabular}{|c|c|c|c|}
\hline \multicolumn{2}{|c|}{ Skin/ Fasciocutaneous } & \multirow{2}{*}{$\begin{array}{c}\text { No. of cases (\%) } \\
25(16.8 \%) \\
4(2.7 \%) \\
2(1.3 \%)\end{array}$} & \multirow{2}{*}{$\begin{array}{c}\text { Complications reported } \\
\text { Donor site scar, bulky in females, Hematoma }\end{array}$} \\
\hline 1 & $\begin{array}{ll}\text { Paraumbilical perforator based flaps } \\
\text { - } & \text { Oblique (Thoraco umbilical) } \\
\text { - } & \text { Transverse (Thoraco epigastric) } \\
\text { - } & \text { Thoraco abdominal (random pattern) }\end{array}$ & & \\
\hline 2 & Lateral intercostal perforator based flap & $8(5.4 \%)$ & Scar, Bulky flap \\
\hline 3 & External oblique fasciocutaneous & $5(3.3 \%)$ & $\begin{array}{l}\text { Donor site scar, Cellulitis of abdominal wall- } \\
\text { treated with antibiotics }\end{array}$ \\
\hline 4 & Islanded Parascapular flap & $1(0.6 \%)$ & None reported \\
\hline 5 & Extended/ BIlateral Groin & $3(2 \%)$ & None reported \\
\hline \multicolumn{4}{|c|}{ Muscle/ myocutaneous flaps } \\
\hline 1 & Latissimus dorsi & $96(64.8 \%)$ & $\begin{array}{l}\text { Donor site seroma, wound infection, dehiscence, } \\
\text { partial skin graft loss }\end{array}$ \\
\hline 2 & Rectus abdominis & $4(2.7 \%)$ & Abdominal wall laxity, hernia, Bulky flap \\
\hline
\end{tabular}

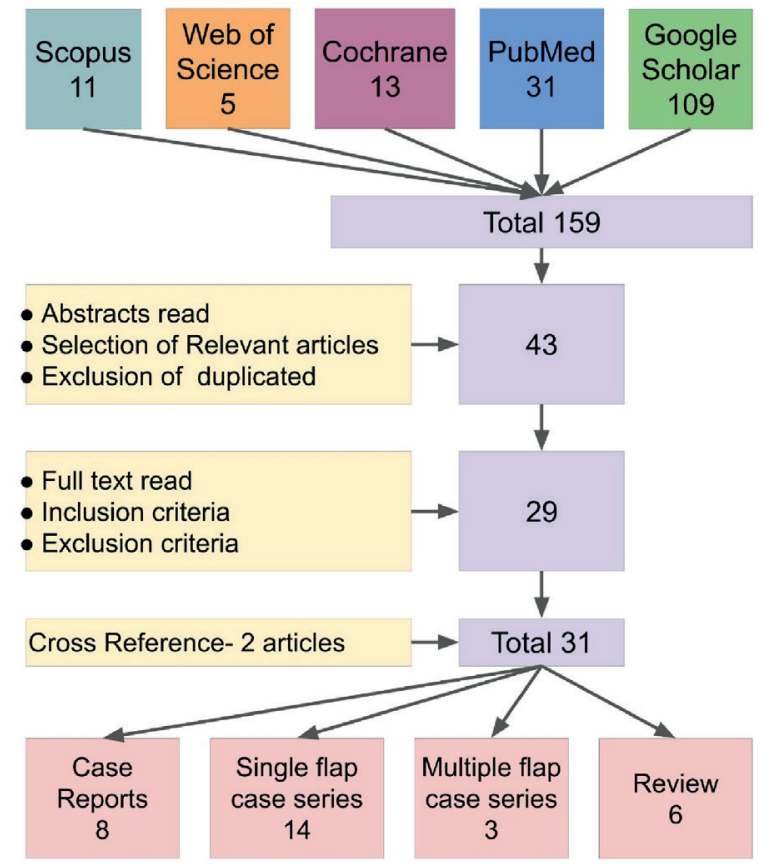

Figure 1. Flowchart diagram showing the process of systematic review

\section{Clinical and Research Consequences}

Various pedicled flaps have been described in the literature, that can be broadly classified into skin or fasciocutaneous flaps and muscle or myocutaneous flaps. (Fig. 2).

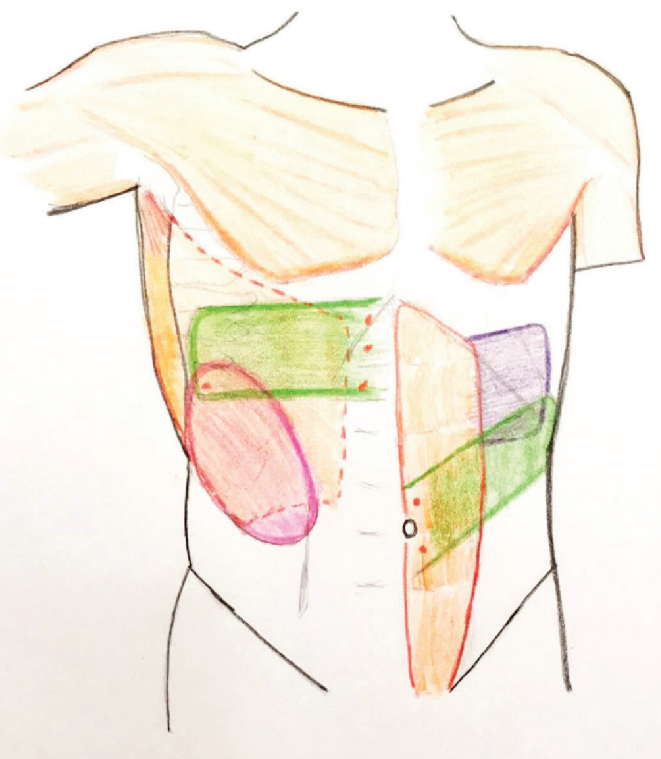

Figure 2. Representative diagram showing common pedicled flaps from abdomen. a. (Pink): Intercostal perforator flap; b. (Purple): Thoracoabdominal flap; c. (Green) Thoracoumbilical flap; d. (Green): Thoracoepigastric flap. Also outlined are the muscle flaps rectus abdominis (e) and latissimus dorsi (f)

\section{A. Skin or Fasciocutaneous flaps from abdomen for elbow coverage}

The vascularity of the anterior abdomen mainly consists of the perforators of superficial and deep inferior epigastric circulation medially, and segmen- 
tal branches of intercostal, subcostal and lumbar arteries laterally (6). The fasciocutaneous flaps follow a similar pattern.

\section{a. Medially based flaps}

Earlier publications of use of abdominal skin for coverage of elbow defects were predominantly about random flaps. Based on their location and pattern, they were named thoracoabdominal, thoracoepigastric, thoracoumbilical, etc. With increase in the awareness of vascularity of the abdominal wall, the nomenclature of such flaps has changed. There are numerous terminologies used for these flaps with considerable overlap, especially for the umbilical perforator based flaps. Depending on its geometrical design, the flap has been named as thoracoumbilical flap, thoracoepigastric flap, extended deep inferior epigastric artery flap, paraumbilical flap or oblique paraumbilical perforator-based flap.

As it is appropriate to name the flap based on its principal blood supply, we recommend the term paraumbilical perforator flap. The location and direction of the flap determines whether it is oblique or transverse. Oblique flaps extend from the umbilical (thoracoumbilical) to the thoracic region, and transverse flaps extend from the epigastric region (thoracoepigastric) to the thoracic region. We have provided the following nomenclature for better understanding and communication.

i. Thoracoumbilical: This term should be reserved for flaps which have their base around the umbilicus and extend laterally and superiorly towards the lateral chest wall. The vascularity is based on paraumbilical perforators.

ii. Thoracoepigastric: This term should be used for flaps which have a transverse orientation with their base in the epigastric area and extending laterally towards the chest wall. Their vascularity is based on the perforating branches of deep inferior epigastric and internal mammary networks.

iii. Thoracoabdominal: We propose this term to be reserved for random pattern flaps. They can be anteriorly based or posteriorly based. The term tho- raco-abdominal flap should be limited to broad based random pattern flaps as the term thoracoabdominal is nonspecific and does not specify the underlying blood supply nor orientation.

\section{i. Thoracoumbilical flaps}

Thoracoumbilical flaps have their bases at the umbilicus and derive their blood supply from paraumbilical perforators. Seitchik and Garnick were the first to describe such a flap for elbow coverage (8). They named it extended deep inferior epigastric artery flap as they extended it to the level of the scapular tip. However, this was often complicated with tip necrosis of the flap. With advances in the knowledge of the vascular anatomy of the abdomen, O'Shaughnessy and Ralwani termed this flap "oblique paraumbilical perforator flap”. This flap was based on the paraumbilical perforators of the deep inferior epigastric artery and its anastomosis between the perforators of the intercostal vessels (9). In the two cases described by the authors, one was for a proximal forearm and elbow, and the second was for a below elbow amputation stump. The authors noted that this design allows for a longer length of the flap and comfortable positioning compared to other pedicled flaps.

Similar observations were noted by Naduthodikayil and Bhandari, who in addition noted that this flap would place the hand in a nondependent position (10). They noted that 3-4 perforators were consistently present at the base of the flap obviating a need for a preoperative Doppler examination. Their series of 11 patients included a case of circumferential elbow defect, which is a challenge to reconstruct. Naduthodikayil and Bhandari were successful in covering the circumferential elbow defect with the oblique design and delay of the flap posterior to the mid-axillary line. This significant achievement demonstrated the importance of pedicled abdominal flaps for elbow coverage and, importantly, limb salvage. Ramadevi and Kumar demonstrated successful reconstruction of defects on the volar, dorsal, medial and lateral aspect of the elbow with this flap (11). As recommended by several authors, we recommend delaying the flap when extending beyond the mid-axillary line. 
In this review, we found that thoracoumbilical flaps were the most commonly used fasciocutaneous flaps for elbow coverage. This flap has the advantage of long length, ability to close the donor site primarily, nondependent positioning of the hand. The drawbacks include scar widening.

\section{ii. Thoracoepigastric flaps}

These flaps are based on the epigastric region and extend to the thoracic region. The upper margin of the flap is at inframammary fold, the lower margin about $10-16 \mathrm{~cm}$ caudal to the upper margin. This flap is based on the perforators of the deep inferior epigastric artery and the internal mammary artery.

Davis and McCraw reported this flap as "Thoracoabdominal flap" in 38 patients. Although they predominantly used this flap for mastectomy and chest wall defects, they also used it for elbow defects. They noted that the axial supply extends till anterior axillary line and any extension further is random pattern (7). They emphasized the importance of including fascia with the flap and including the vessels perforating the rectus sheath, failure to do so would jeopardize the flap. Hallock and Dingeldien described the use of flap which was similar to the one described by Davis and termed it more appropriately as "thoracoepigastric flap". Like the description by Davis, the upper margin was in inframammary fold and the lower margin was $10-16 \mathrm{~cm}$ caudal to upper margin. They also suggested delaying the flap if it extends beyond the posterior axillary line. They reported two patients with post-burn elbow defects where they used this flap successfully for coverage (6). This flap has been largely replaced by the thoracoumbilical flap as described above.

\section{iii. Thoracoabdominal flaps (Random pattern flaps)}

As mentioned previously, we reserved the term thoracoabdominal for random pattern flaps emerging from the chest and abdominal wall. The term thoracoabdominal is nonspecific and does not state the orientation or vascularity (Fig. 3 ).

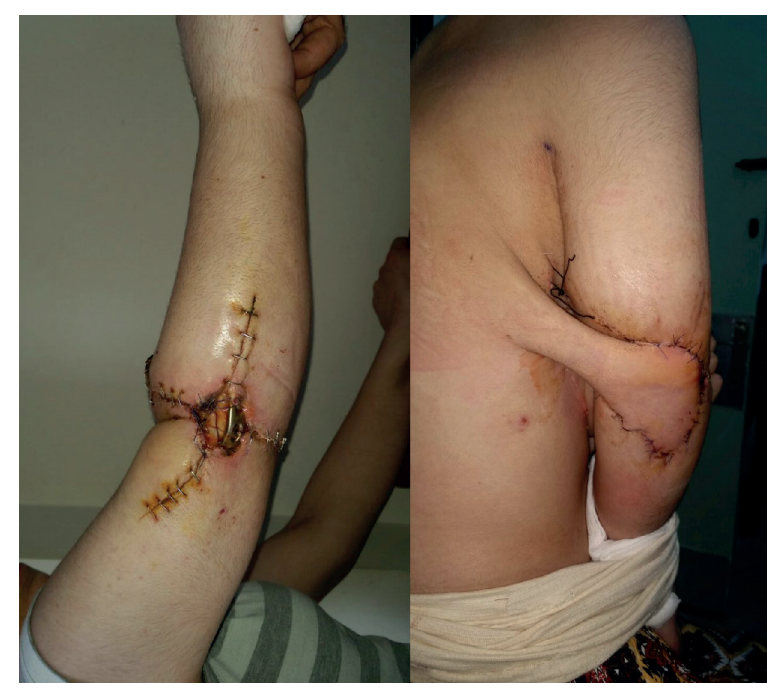

Figure 3. A case with an exposed elbow arthrodesis plate after resection of a giant cell tumor. Exposed flap was covered with a pedicled thoracoabdominal flap

Even in the era of microsurgery, these pedicled flaps have a role in treatment of both civilian and military injuries. In case of military injuries, Farber and Taylor noted that free flaps are often not a viable solution because vascular tie-in points are often compromised or a far proximal anastomosis is needed, that is not practical (12). In their series of 2 patients, Farber et al used this flap based both anteriorly and posteriorly. They noted several advantages such as adequate soft tissue coverage of small to significant size and durability of the flap over joint motion and prosthetic wear. These flaps were broad based and not dependent on any single source vessel. Hence, they are likely to have a "random pattern" vascularity.

\section{b. Laterally based flaps}

\section{i. Intercostal perforator based flap}

The use of lateral intercostal perforator-based flaps for reconstruction of elbow defects was described by Yunchuan and Jiaqin et al (13). These flaps were based on the lateral cutaneous branch of the posterior intercostal artery. The authors preferred the area between the 7th and 10th intercostal space. The flap could be designed as vertical, oblique or short transverse. Flaps measuring up to $16 \times 12 \mathrm{~cm}$ were demonstrated by the authors. The authors believe that patient positioning is superior with this flap compared to other flaps. 
Further, intercostal perforator flaps can be harvested from the contralateral side.

Pirela-Cruz and Reddy et al described an anteriorly based, intercostal perforator flap (14). While posteriorly based flaps are solely dependent on intercostal perforators, the anteriorly based flaps do receive contribution from periumbilical perforators based on the location.

\section{ii. External oblique fasciocutaneous flap}

This flap is based on the perforators entering the skin through the external oblique muscle. Flap elevation begins on the lateral margin of the rectus abdominis muscle. The external oblique aponeurosis is included in the flap. As flap dissection proceeds laterally, the fascia overlying external oblique muscle is included in the flap, dissecting it off the muscle fibers. This dissection is continued until the mid-axillary line when the vascular pedicle comes into view. Fisher described the use of external oblique fasciocutaneous flap in five patients in 1983 (15). Flaps measuring up to $8 \times 18 \mathrm{~cm}$ were used, predominantly for posterior defects of the elbow.

\section{Other Less Common Fasciocutaneous Flaps}

Our literature review resulted in some uncommon flaps. Leena reported the use of pedicled parascapular flaps for coverage of elbow stump in a single stage reconstruction (16). The parascapular flap is based on the circumflex scapular artery, which has a pedicle length up to $10 \mathrm{~cm}$. The flap was eccentrically based in order to gain more length. The flap was tunneled through the posterior axillary fold to reach the defect. Reyad and Tallal reported a case of bilateral groin and hypogastric flap for coverage of an extended wound involving elbow, forearm and hand (17).

\section{B. Muscle or myocutaneous flaps from abdomen for elbow coverage}

The two main muscle flaps from the abdomen include latissimus dorsi and rectus abdominis.

\section{a. Latissimus dorsi (LD)}

$\mathrm{LD}$ is a large muscle with a wide arc of rotation. It can be used for a variety of defects including the elbow. Ooi and $\mathrm{Ng}$ et al have described LD to be the workhorse flap for elbow reconstruction (18). Its advantages include coverage of large surface area, reliable and constant blood supply, the ability to reconstruct in a single stage procedure without need for immobilization, minimal donor site morbidity in most patients and the possibility of using it as a functional muscle transfer for elbow flexion or extension. Schottstaedt et al first described functional muscle transposition (19). This work was further elaborated by Zancolli and Mitre (20). Jutte and Rees et al described the use of pedicled LD flaps to cover soft tissue defects at the elbow (21). In a detailed description Stevanovic and Sharpe et al even went on to suggest using pedicled LD as a prophylactic measure in complex elbow injuries (3).

LD can be used as a muscle flap with skin grafting over the muscle, and it can be used as a myocutaneous flap with a skin island overlying the muscle (Fig. 4, Fig 5). The island can be designed obliquely or transversely in women to hide under the brassiere. Skin islands as large as $8 \times 20 \mathrm{~cm}$ can be closed primarily. The anterior transposition can reach $8.4 \mathrm{~cm}$ distal to olecranon, while the posterior transposition can reach up to $6.5 \mathrm{~cm}$ distal to olecranon. Stevanovic et al recommend incising the skin overlying the trans-
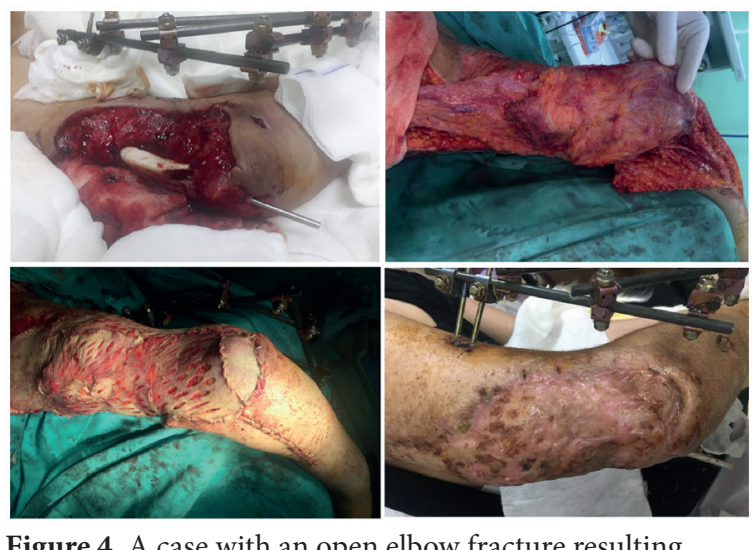

Figure 4. A case with an open elbow fracture resulting from a motor vehicle accident. Ulnar nerve defect was reconstructed with a sural nerve graft and the soft tissue defect was covered with a pedicled latissimus dorsi musculocutaneous flap and split thickness skin graft 


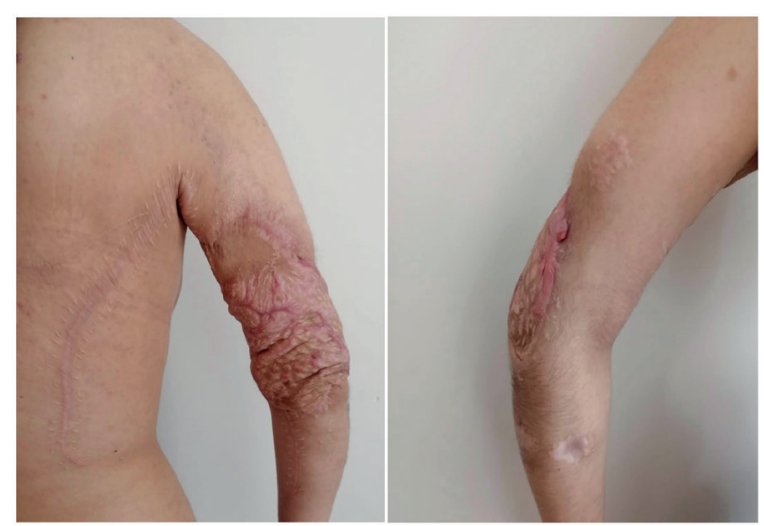

Figure 5. The case presented in Fig. 4 eleven months after wound coverage with pedicled latissimus dorsi musculocutaneous flap

posed muscle rather than a subcutaneous tunnel to avoid pressure on the pedicle.

To cover a very large area following soft tissue sarcoma resection and axillary node dissection, Nicoli and Orfaniotis et al used the latissimus dorsi with its skin paddle continuing onto groin flap including inguinal nodes. The large myocutaneous flap was transposed and supercharged by anastomosing superficial circumflex iliac artery to radial artery (22). While the LD muscle acted as a functional transfer, the inguinal nodes were transferred to prevent upper limb edema.

Use of LD muscle can be contraindicated in patients who would need lifelong crutch or wheelchair use. Caution should be exercised while using them in patients who have a high risk of breast cancer as it may be needed for future breast reconstruction.

\section{b. Rectus abdominis}

The less common muscle flap from the abdomen is the rectus, which can be used as a muscle only flap with a skin graft or as a myocutaneous flap. However, compared to LD, the rectus flap is a two staged procedure and would need a division after three weeks. Further, loss of rectus is not without complications. Hence, this flap has fallen out of favor for elbow defects and replaced by the fasciocutaneous flaps previously listed. The discussion is mainly of academic interest.

Sbitany and Wray described a case of post traumatic infected elbow coverage with superiorly based rectus abdominis muscle flap with skin graft. The flap was divided after three weeks and the superior part of the muscle was returned to the abdomen. (23). Similarly, Burstien and Salomon described transverse rectus island flap, where a transverse skin island was harvested based on a superiorly based rectus muscle. This flap was applied in three patients with elbow defects (24).

\section{CONCLUSION}

Even in the era of microsurgery, there is a definite role for pedicled flaps in elbow reconstruction. Knowledge about these flaps is very beneficial in salvaging the elbow in difficult clinical situations. These flaps can be the back-up or even preferred flaps in elbow and limb salvage. Based on our review, we found that $\mathrm{LD}$ is the most common pedicled abdominal flap used for reconstruction of elbow defects. It has many advantages - being a single stage procedure, not requiring immobilization and the ability to provide motor function. Among the fasciocutaneous flaps, the paraumbilical perforator-based flaps appears to be the most frequently utilized. This flap has the potential to be used for coverage of circumferential elbow defects. However, donor site scar and a necessary period of immobilization are some of potential drawbacks associated with its use. Other less frequently used flaps are thoracoabdominal, thoracoepigastric, intercostal perforator based flaps and parascapular flaps. These fasciocutaneous flaps have replaced the rectus abdominis muscle flap for this purpose. There is a discrepancy in the nomenclature of fasciocutaneous flaps. With better understanding of flap circulation and vascular basis, the terminology of flaps has been evolving. We have provided a simplified definition for better understanding and communication.

Hakem Değerlendirmesi: Dış bağımsız.

Peer Review: Externally peer-reviewed.

Yazar Katkıları: Çalışma Konsepti/Tasarım- Ö.B, H.U.A.; Veri Toplama- S.S.A., H.S.B., H.B.; Veri Analizi/Yorumlama- Ö.B, H.U.A.; Yazı Taslağ1- Ö.B, H.U.A.; İçeriğin Eleştirel İncelemesi- Ö.B.; Son Onay ve Sorumluluk- Ö.B, H.U.A.

Author Contributions: Conception/Design of Study- Ö.B, H.U.A.; Data Acquisition- S Ö.B, H.U.A; 
Data Analysis/Interpretation- Ö.B, H.U.A.; Drafting Manuscript- Ö.B, H.U.A.; Critical Revision of Manuscript- Ö.B.; Final Approval and Accountability- Ö.B, H.U.A.

Çıkar Çatışması: Yazarlar çıkar çatışması beyan etmemişlerdir

Conflict of Interest: Authors declared no conflict of interest.

Finansal Destek: Yazarlar finansal destek beyan etmemişlerdir.

Financial Disclosure: Authors declared no financial support.

\section{REFERENCES/KAYNAKLAR}

1. Choudry UH, Moran SL, Li S, Khan S. Soft-tissue coverage of the elbow: an outcome analysis and reconstructive algorithm. Plast Reconstr Surg. 2007;119(6):1852-1857.

2. Kelley BP, Chung KC. Soft-Tissue Coverage for Elbow Trauma. Hand Clin. 2015;31(4):693-703.

3. Stevanovic M, Sharpe F, Thommen VD, Itamura JM, Schnall SB. Latissimus dorsi pedicle flap for coverage of soft tissue defects about the elbow. J Shoulder Elbow Surg. 1999;8(6):634-643

4. Jensen M, Moran SL. Soft tissue coverage of the elbow: a reconstructive algorithm. Orthop Clin North Am. 2008;39(2):251-vii.

5. Khan KS, Kunz R, Kleijnen J, Antes G. Five steps to conducting a systematic review. J R Soc Med. 2003;96(3):118-121

6. Hallock GG, Dingeldein GP. The Thoracoepigastric Flap as an Alternative for Coverage of the Burned Elbow. J Burn Care \& Rehab.1982;3(6),393-396.

7. Davis WM, McCraw JB, Carraway JH. Use of a direct, transverse, thoracoabdominal flap to close difficult wounds of the thorax and upper extremity. Plast Reconstr Surg. 1977;60(4):526-533.

8. Seitchik SH, Granick MS, Solomon MP, Berman AT. Posttraumatic upper extremity wound coverage utilizing the extended deep inferior epigastric flap. Ann Plast Surg. 1992;28(5):465-471

9. O'Shaughnessy KD, Rawlani V, Hijjawi JB, Dumanian GA. Oblique pedicled paraumbilical perforator-based flap for reconstruction of complex proximal and mid-forearm defects: a report of two cases. J Hand Surg Am. 2010;35(7):1105-1110

10. Naduthodikayil P, Bhandari L, Sreedhar SL. Pedicled Oblique Para-Umbilical Perforator (OPUP) Flap for Upper Limb Reconstruction. J Hand Surg Asian Pac Vol. 2016;21(2):229-233.

11. Ramadevi V. Pedicle Thoracoumbilical Flap for Soft Tissue Coverage Defects Around Elbow Region. IOSR J Dent \& Med Sci. 2019;18(2):23-27.

12. Farber GL, Taylor KF, Smith AC. Pedicled thoracoabdominal flap coverage about the elbow in traumatic war injuries. Hand (N Y). 2010;5(1):43-48.

13. Yunchuan P, Jiaqin X, Sihuan C, Zunhong L. Use of the lateral intercostal perforator-based pedicled abdominal flap for upper-limb wounds from severe electrical injury. Ann Plast Surg. 2006;56(2):116-121

14. Pirela-Cruz MA, Reddy KK, Higgs M. Soft tissue coverage of the elbow in a developing country. Tech Hand Up Extrem Surg. 2007;11(3):214-220

15. Fisher J. External oblique fasciocutaneous flap for elbow coverage. Plast Reconstr Surg. 1985;75(1):51-61

16. Leena J. Islanded Parascapular Flap: An Above Elbow Stump Cover. Anaplastology. 2015; 4(1): 144.

17. Reyad KA, Talal RS. Bilateral Combined Groin and Hypogastric Flap for Coverage of Extremely Huge Combined Hand, Forearm and Elbow Defects. Egypt, J. Plast. Reconstr. Surg. 2019; 43(3) 545-547.

18. Ooi A, Ng J, Chui C, Goh T, Tan BK. Maximizing Outcomes While Minimizing Morbidity: An Illustrated Case Review of Elbow Soft Tissue Reconstruction. Plast Surg Int. 2016;2016:2841816.

19. Schottstaedt ER, Larsen LJ, Bost FC. Complete muscle transposition. J Bone Joint Surg Am. 1955;37-A(5):897-919.

20. Zancolli E, Mitre H. Latissimus dorsi transfer to restore elbow flexion. An appraisal of eight cases. 
J Bone Joint Surg Am. 1973;55(6):1265-1275

21. Jutte DL, Rees R, Nanney L, Bueno R, Lynch JB. Latissimus dorsi flap: a valuable resource in lower arm reconstruction. South Med J. 1987;80(1):37-40.

22. Nicoli F, Orfaniotis G, Lazzeri D, et al. The latissimus dorsi-groin-lymph node compound flap: A comprehensive technique with three features including skin coverage, restoration of motor function, and prevention of upper limb lymphedema. Microsurgery. 2016;36(8):689694.

23. Sbitany U, Wray RC Jr. Use of the rectus abdominis muscle flap to reconstruct an elbow defect. Plast Reconstr Surg. 1986;77(6):988-989

24. Burstein FD, Salomon JC, Stahl RS. Elbow joint salvage with the transverse rectus island flap: a new application. Plast Reconstr Surg. 